\title{
Effects of Oral Administration of Aqueous Extract of Hibiscus sabdariffa on Some Haematological Parameters of Wistar Albino Rats
}

\author{
C. U. Emelike* and D. V. Dapper \\ Haemorheology Research Unit, Department of Human Physiology, \\ College of Health Sciences, University of Port Harcourt, \\ PMB 5323, Port Harcourt, Nigeria
}

\begin{abstract}
The effects of oral administration of Hibiscus sabdariffa aqueous extract on some haematological parameters of wistar albino rats were studied. A total of twenty five (25) male albino rats were grouped randomly into groups. Group A (control), Group B (0.6g/100ml of water of HS extract) Group C $(1.2 \mathrm{~g} / 100 \mathrm{ml}$ HS extract), Group D $(1.8 \mathrm{~g} / 100 \mathrm{ml} \mathrm{HS} \mathrm{extract)}$ and Group $E(1.8 \mathrm{~g} / 100 \mathrm{ml}+$ vitamin $C)$ and treatment period was 28 days. A decrease in body weight of the rats was observed except in Group A (control) and Group E. Haematological parameters; (Haemoglobin (Hb), packed cell volume (PCV), total white blood cells (WBC) and differentials) increased significantly $(p<0.05)$ in all the groups when compared with Group A (control) in a dose dependent manner. The study suggests that administration of aqueous extract of Hibiscus sabdariffa might be beneficial to the haematopoietic system.
\end{abstract}

Key Words: Body weight, Haemoglobin, Hibiscus sabdariffa, packed cell volume, and White blood cell

\section{Introduction}

Hibiscus sabdariffa is an annual herbaceous herb belonging to the malvaceace family. It is cultivated for leaf, fleshy calyx, seed or fibre and is often used in traditional medicine. The calyx of the plant is also use as refrigerant in the form of tea, popularly known as zobo in Nigeria. The chemistry of the dried calyx revealed that per $100 \mathrm{~g}$, it contains 49 calories, 84.5 percent water, $1.9 \mathrm{~g}$ protein, $0.1 \mathrm{~g}$ fat, $12.3 \mathrm{~g}$ total carbohydrates, $2.3 \mathrm{~g}$ fibre, $1.2 \mathrm{~g}$ ash, $1.72 \mathrm{mg}$ calcium, $57 \mathrm{mg}$ phosphorous, $2.9 \mathrm{mg}$ iron and $14 \mathrm{mg}$ ascorbic acid. The presence of saponins, tannins and cyanogenic glycosides has been reported [1].

It has been reported to have antihypertensive, hepatoprotective, antihyperlipidemic, anticancer and antioxidant properties. Others include antiseptic, aphrodisiac (an agent that stimulates sexual excitement), astringent (a drug that causes cells to shrink by precipitating proteins from their surfaces, they protect the skin and reduce bleeding from minor abrasions), cholagogue (a drug that stimulates the flow of bile from the gall bladder and bile ducts into the duodenum), demulcent (a soothing agent that protects the mucous membranes and relieves irritation), emollient (an agent that soothes and softens the skin), digestive, purgative and sedative $[2,3,4,5]$.

From the foregoing, this study is aimed at evaluating the effects of oral administration of aqueous extract Hibiscus sabdariffa on some haematological parameters of wistar albino rats.

\subsection{Preparation of extract}

\section{Materials And Methods}

Mature dry dark-red calyces of Hibiscus sabdariffa were purchased from a local market in Port Harcourt, Nigeria and authenticated by Mr. Ogbonnaya Obioma at the National Root Crops Research Institute (NRCRI) Umudike, Umuahia, Abia State, Nigeria. The extraction procedure that was used as described previously [6]. Briefly, $30 \mathrm{~g}$ of the dry petals of Hibiscus sabdariffa were brewed in $400 \mathrm{ml}$ of boiled tap water for 45 minutes. The resulting decoction was filtered using a filtration sieve (pore size $0.5 \mathrm{~mm}$ diameter). It is expected that $10 \mathrm{ml}$ of the filtrate will evaporate to dryness and yielding $0.3665 \pm 0.002 \mathrm{~g}$, giving a concentration of $36.65 \pm 0.002 \mathrm{mg} / \mathrm{ml}$.

The concentration in the exposed group above is derived as follows: $48 \mathrm{ml}$ of tap water were added to $10 \mathrm{ml}$ of filtrate to make approximately $0.6 \mathrm{~g} / 100 \mathrm{ml}$ tap water (Group B), $29 \mathrm{ml}$ of tap water were added to $10 \mathrm{ml}$ of filtrate to make approximately $1.2 \mathrm{~g} / 100 \mathrm{ml}$ (Group C), $9 \mathrm{ml}$ of tap water will be added to $10 \mathrm{ml}$ of filtrate to make approximately $1.8 \mathrm{~g} / 100 \mathrm{ml}$ tap water (Group D), while, $9 \mathrm{ml}$ of tap water will be added to $10 \mathrm{ml}$ of filtrate to make approximately $1.8 \mathrm{~g} / 100 \mathrm{ml}$ tap water $+200 \mathrm{mg}$ vitamin C (Group E). 


\subsection{Experiment animals}

Twenty five (25) male wistar albino rats weighing 180-200g were obtained from the Animal House of Department of Human Physiology, University of Port Harcourt. The animals were housed under a standard laboratory condition with 12 hours dark/light cycle and with access to standard diet (Guinea feed, Benin-Auchi

Road, Edo State) and water ad libitum. The experiment animals were divided randomly into five (5) groups of five (5) animals each. Group A (control) were given tap water to drink. Group B, Group C and Group $\mathrm{D}$ were be given $0.6 \mathrm{~g}$ HS extract, $1.2 \mathrm{~g}$ HS extract and $1.8 \mathrm{~g}$ HS extract respectively in $100 \mathrm{ml}$ tap water. Group E were given $1.8 \mathrm{~g}+$ vitamin C of HS extract in $100 \mathrm{ml}$ tap water for 28 days.

Haematological parameters estimations were carried out on the twenty ninth (29) day of the extract administration.

\subsection{Collection of blood samples}

Precautions were taken on proper collection of the samples. About $2 \mathrm{ml}$ of blood samples were collected from the tail of each rat. The tail end of the rats was completely and neatly cut, at a point $2 \mathrm{~cm}$ from the tip using a sterile surgical blade. The blood samples were collected in $\mathrm{K}_{3}$ EDTA tubes. The blood collected was used for haematological parameters.

\subsection{Blood analysis}

The haematological parameters performed were according to standard methods. Measurement of Hemoglobin was estimated by using cyanomethaemoglobin technique. Packed cell volume of each sample was determined by using a Hawksley microhaematocrit centrifuge at 12,000 rpm for five minutes [7]. Total white blood cells were counted using the improved Neubauer haemocytometer [8].

\subsection{Statistical analysis}

The data of body weights and haematological parameters were analyzed using the Statistical Package for Social Sciences (SPSS for windows, version 12.0). Comparisons were made between control and experimental groups using student's t-test. Values of less than 0.05 were regarded as statistically significant. Tables and Chart were also used to represent data obtained from the analysis.

\section{Body weight}

\section{Results}

The body weight of the wistar albino rats were measured before and after the administration of the extract. The correlation between the initial weight and final weight is shown in Table 1 and Fig. 1. It was observed that there were significant decrease $(\mathrm{P}<0.05)$ in all the groups except control group and $1.8 \mathrm{~g} / 100 \mathrm{ml}$ of HS (Group A and Group F).

\section{Haematological parameters}

Some haematological parameters: (Haemoglobin $(\mathrm{Hb})$, packed cell volume (PCV), Total White blood cells (WBC) and Differential WBC (Diff) were measured. The mean and standard deviation are shown in Table 2. Results obtained showed a significant increase $(P<0.05)$ in all the groups when compared with the control (Group A). The mean hemoglobin of Group C, D and E was significantly higher than that of Group A and B $(\mathrm{P}<0.05)$. Group $\mathrm{C}, \mathrm{D}$ and $\mathrm{E}$ showed significant increase when compared with the control (Group A). There was significant difference in groups when compared with the control (Group A) as shown in Table 2.

Table 1: Effect Of Aqueous Extracts Of Hibiscus Sabdariffa On Weight Of Wistar Albino Rats

\begin{tabular}{cccccc}
\hline GROUP A & GROUP B & GROUP C & GROUP D & GROUP E \\
PARAMETERS CONTROL & $0.6 \mathrm{~g} / 100 \mathrm{ml}$ & $1.2 \mathrm{~g} / 100 \mathrm{ml}$ & $1.8 \mathrm{~g} / 100 \mathrm{ml}$ & $1.8 \mathrm{~g} / 100 \mathrm{ml}$ \\
(Tap water) & HS & HS & HS & + Vit. C \\
\hline Initial weight $(\mathrm{gm})$ & $182.00 \pm 14.83$ & $196.20 \pm 11.30$ & $206.6 \pm 8.53$ & $212.8 \pm 7.25$ & $180.2 \pm 15.97$ \\
Final weight $(\mathrm{gm})$ & $217.00 \pm 8.43$ & $192.40 \pm 10.31 *$ & $203.00 \pm 4.12 *$ & $198.80 \pm 4.21 *$ & $214.40 \pm 4.83$ \\
\hline
\end{tabular}

Values are expressed as mean $\pm \mathrm{SD}$

*significantly different statistically from the controls $(\mathrm{p}<0.05)$ 
Fig.1. Initial and final body weight of wistar albino rats after experiment in Group A (control), Group B $(0.6 \mathrm{~g} / 100 \mathrm{ml}$ of HS extract) Group C (1.2g/100ml HS extract) Group D $(1.8 \mathrm{~g} / 100 \mathrm{ml}$ HS extract) and Group $\mathrm{E}(\mathbf{1 . 8 g} / \mathbf{1 0 0 m l}+$ Vitamin C)

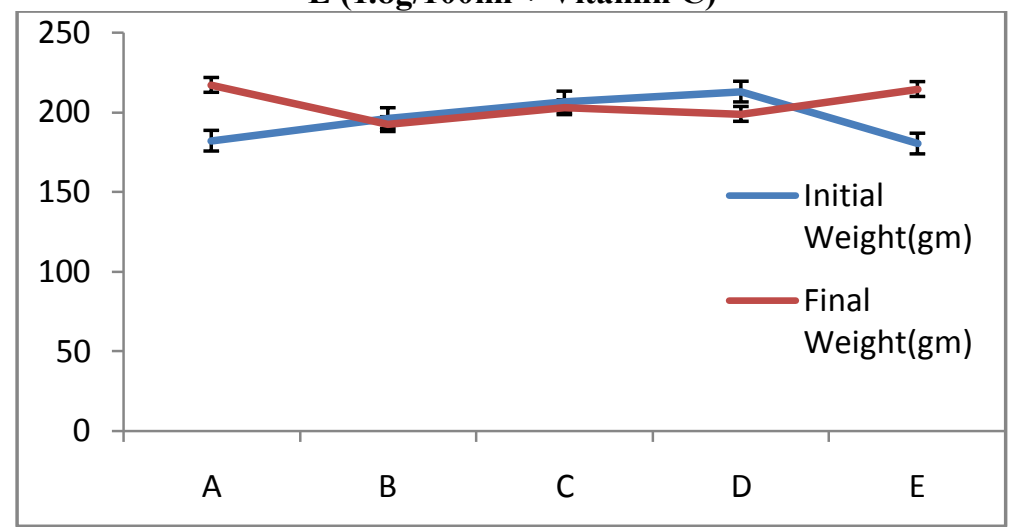

Table 2: Hematological Parameters Of Aqueous Extracts Of Hibiscus Sabdariffa On Wistar Albino Rats

\begin{tabular}{|c|c|c|c|c|c|}
\hline PARAMETERS & $\begin{array}{l}\text { GROUPA } \\
\text { CONTROL } \\
\text { (Tap water) }\end{array}$ & $\begin{array}{c}\text { GROUPB } \\
0.6 \mathrm{~g} / 100 \mathrm{ml} \\
\mathrm{HS}\end{array}$ & $\begin{array}{l}\text { GROUPC } \\
1.2 \mathrm{~g} / 100 \mathrm{ml} \quad 1.8 \\
\mathrm{HS}\end{array}$ & $\begin{array}{l}\text { GROUPD } \\
8 \mathrm{~g} / 100 \mathrm{ml} \quad 1,8 \mathrm{~g} \\
\mathrm{HS}\end{array}$ & $\begin{array}{l}\text { GROUPE } \\
+100 \mathrm{ml} \\
+\mathrm{Vit} . \mathrm{C}\end{array}$ \\
\hline Hemoglobin (g/dl) & $8.34 \pm 3.51$ & $10.68 \pm 2.57$ & $12.48 \pm 1.21^{*}$ & $12.06 \pm 1.13^{*}$ & $13.02 \pm 0.45^{*}$ \\
\hline Packed cell volume & $\% 28.0 \pm 11.51$ & $35.6 \pm 8.56$ & $41.6 \pm 4.03^{*}$ & $40.2 \pm 3.76^{*}$ & $43.4 \pm 1.52^{*}$ \\
\hline $\begin{array}{l}\text { White blood cell } \\
\text { (T) }\left(10^{\ominus} \mathrm{L}\right)\end{array}$ & $24.82 \pm 3.72$ & $22.56 \pm 5.27$ & $10.44 \pm 1.67^{*}$ & $7.92 \pm 0.89^{*}$ & $10.22 \pm 1.73^{*}$ \\
\hline $\begin{array}{l}\text { White blood cell } \\
\text { (Diff) Neutrophil }\end{array}$ & $\begin{array}{l}16.2 \pm 10.13 \\
1 \%\end{array}$ & $19.8 \pm 13.26$ & $44.0 \pm 16.54^{*}$ & $61.6 \pm 2.30^{*}$ & $27.6 \pm 3.65$ \\
\hline $\begin{array}{l}\text { White blood cell } \\
\text { (Diff) lymphocyt }\end{array}$ & $\begin{array}{l}83.8 \pm 10.13 \\
\text { te } \%\end{array}$ & $75.0 \pm 12.74$ & $54.6 \pm 11.90^{*}$ & $38.4 \pm 2.30^{*}$ & $72.4 \pm 3.64$ \\
\hline
\end{tabular}

Values are expressed as mean \pm SD

*Significantly different statistically from the controls $(\mathrm{p}<0.05)$

\section{Discussion}

Decrease in body weights of the rats except in the Group A (control) and Group E could be due to very sour taste of $\mathrm{H}$. sabdariffa which may reduce appetite which caused decrease in food intake or consumption which ultimately lead to decrease in the weights observed $[9,10,11]$ or alternatively it may have some effect on glucose or lipid metabolism.

The results obtained from this work revealed that haematological parameters (Haemoglobin $(\mathrm{Hb})$, Packed Cell Volume (PCV), Total White blood cells $(\mathrm{WBC})$ and Differential) increased significantly $(\mathrm{P}<0.05)$ in all the groups when compared with Group A (control) in a dose dependent. This is in agreement with the report of Adigun, et al., (2006) where it was reported that Hibiscus sabdariffa is used in the management of anemia.

Haemoglobin concentration and packed cell volume (PCV) have been used to detect anemia and its severity and to monitor an anemic patient's response to treatment [14]. Studies have shown that some substances like food and leaves have been associated with increase or decrease in Hb and PCV [5]. In this study, we observed that the extracts increased the $\mathrm{Hb}$ and PCV of albino rats (Table 2). This study is in agreement with the study of Adigun et al., (2006) who suggested that aqueous extract of HS are beneficial on the red cells at short term uses which may be sustained at long term uses. The findings in this study suggest that the extract may be useful in improving the $\mathrm{Hb}$ and PCV for a long term administration.

The white blood cells have been known to play very important roles in improving the immune system [14]. The total white blood cells of albino rats used in this study recorded a significant increase $(\mathrm{P}<0.05)$ after 28days. This could be attributed to the possible stimulation of the immune system by the extract [15].

The blood lymphocytes are part of the immune cells which plays an important role in protection against pathogens. The lymphocytes are specialized in recognizing antigens on living cell that distinguish self from nonself; they are capable of recognizing initially all conceivable antigens [16]. The lymphocyte counts in this study were observed to increase as the time increased during the extracts administration. This is in agreement with the works of Effraim et al., (1999); Adigun et al., (2006). This increase in lymphocytes could be attributed to the 
introduction of aqueous extract of Hibiscus sabdariffa. Nwinuka et al., (2008) in their study on the effect of Hibiscus sabdariffa on the haematopoietic system reported an improvement on the haematological parameters with a similar dose and duration. Thus, while this dose might be beneficial to the haematopoietic system, it is however toxic to the liver.

\section{Conclusion}

Our study suggests that administration of aqueous extract of Hibiscus sabdariffa might be beneficial to the haematopoietic system. It is therefore recommended that further studies be conducted to determine the safe dose of this HS in Humans.

\section{References}

[1] J.A. Duke, and A.A Atchley, B.R Christie, The Handbook of Plant Science in Agriculture (Ed), (CRC Press Inc., Boca Raton. 1984). Page 120-122.

[2] J.M Dalziel, The Useful Plants of West Tropical Africa (The crown Agents, London, 1973), 314-315.

[3] C.J. Wang, J.W. Wang, and H. Tseng, Protective effect of Hibiscus anthocyanins against tert- butyl hydro peroxide induced hepatic toxicity in rats. Food Chem.Toxicol., 38(5), 2000:411-416

[4] L. S. Wang, and G. D. Stoner, Anthocyanins and Their Role in Cancer Prevention," Cancer Letters, Vol. 269, 2008, No. 2, pp. 281290.

[5] I.P. Odigie, R.P Ettarh, and S.A Adigun, Chronic administration of aqueous extract of Hibiscus sabdariffa attenuates hyperten sion and reverses cardiac hypertrophy in 2K-1 hypertensive rats. J Ethnopharmacol, 86: 2003, 181-185.

[6] E. E. Iyare, and O.A., (Adegoke, Maternal consumption of an aqueous extract of Hibiscus sabdariffa during lactation accelerates postnatal weight and delays onset of puberty in female offspring. Niger .J Physiol. Sci., 23, 2008, 89-94.

[7] M.J. Lynch, and S.S. Raphael, Lynch Med. Laboratory Technology (W.B. Saunders company, 4th Ed., 1983) 681-685

[8] E.J. Baker, and R.E Silverton, Introduction to Medical Laboratory Technology (W.B. Saunders company, $6^{\text {th }}$ edition, 1985), page 316-324.

[9] O.J Afonne, C. U. Orisakwe, O. E. Ndubuka, G. I. Akuumfa, and N. A. Ilon-Ilondu, Bio. Pharm Bull 2002, 235-8.

[10] I.P. Odigie, R.P. Ettarh and S.A.Adigun, Chronic administration of aqueous extract of Hibiscus sabdariffa attenuates hypertension and reverses cardiac hypertrophy in 2K-1 hypertensive rats. J Ethnopharmacol, 86, 2003, 181-185.

[11] O.E. Orisakwe, D.C. Hussaini, and O.J. Afonne, Testicular effects of sub-chronic administration of Hibiscus sabdariffa calyx aqueous extract in rats. Repro. Toxicol. 18, 2003, 295-298.

[12] O.E. Orisakwe, D.C. Hussaini, D.N. Akunyili, A.A. Njan, D.D Akumka, O.O. Udemezue, Subchronic administration of Nigerian species of Hibiscus Sabdarffa calyx in rats did not produce cardiotoxicity. Eur. Bull. Drug Res. 12, 2004, 1-5.

[13] M.O. Adigun, O.D. Ogundipe, J.I. Anetor, andA.O. Odetunde, Dose-dependent changes in some Haematological parameters during shor-time administration of Hibiscus sabdariffa calyx aqueous extract (zobo) in Wistar albino rats. Afr. J Med. Sci., 35, 2006, 73 77.

[14] M. Chesbrough, District Laboratory Practice in Tropical Country Part 2 (Second Edition Cambridge University press, 2005 ), 299 320 .

[15] K.D. Effraim, H.A. Salami, and P.A. Nwafor, The effect of aqueous extract of Trigonella Foemun Gracium (Fenugreck) on Haematogical parameters in Albino rats.Afr. J. Biomed, Res; 2; 1991, 24-51.

[16] W.F. Ganong, (2005) Review of Medical Physiology (22 ${ }^{\text {nd }}$ Edition University of California, 2005) Page 515-546.

[17] N.M. Nwinuka, M.O. Monanu and B.I. Nwiloh, Effects of aqueous extract of Mangifera indica L. (Mango) stem bark on haematological parameters of normal albino rats. Pak. J. Nutr., 7(5): 2008, 663-666, ISSN: 1680-5194. 